\title{
Sewage sludge for sustainable agriculture: contaminants' contents and potential use as fertilizer
}

\author{
Lucrezia Lamastra, Nicoleta Alina Suciu* (10) and Marco Trevisan
}

\begin{abstract}
Background: Sewage sludge, the inevitable byproduct of municipal wastewater-treatment plant operation, is a key issue in many countries due to its increasing volume and the impacts associated with its disposal. According to the report of European Commission published in 2010, 39\% of sewage sludge produced in the European Union is recycled into agriculture. Management options require extensive waste characterization, since many of them may contain compounds, which could be harmful to the ecosystem, such as heavy metals, organic pollutants, etc. The present study aims to show the results of 2 years' sampling of sewage sludge-based on 130 samples collected from 35 wastewater-treatment plants situated in the North of Italy-and to assess its suitability as soil fertilizer regarding contents of nonylphenol (NP), nonylphenolethoxylates (NPnEOs), and phthalates (DEHP).

Results: An effective analytic method for organic pollutants detection in the sewage sludge has been developed, showing an excellent repeatability and recoveries. Ecotoxicological risk assessment was evaluated using risk quotients (RQs) for sludge-amended soil. Most of the analyzed samples do not contain NP, NPnEOs, and DEHP at levels higher than the limit established by the draft-working document of the European Commission on Sludge. The assessment using RQs reports that NP and NPnEOs never give values higher than 1, and for DEHP the obtained RQs exceed the value of 1 just three times. Data obtained were compared to the data from other European and Asiatic countries, showing a huge variability for all the compounds considered.

Conclusions: Based on the obtained results, it appears that the proposed EU limits for the selected substances on sewage sludge intended to be used as soil fertilizer in agriculture are sufficiently conservative to avoid negative effects on soil fauna.
\end{abstract}

Keywords: Sewage sludge, Sustainability, Risk quotient, Soil fertilizer

\section{Background}

Sewage sludge is a semisolid residual material resulting from the sedimentation of the suspended solid during the wastewater-treatment processes. Two main types of sewage sludge could be identified: primary sludge that resulted from the capture of suspended solids and organics through gravitational sedimentation, and the secondary sludge that is produced involving microorganisms that consume organic matter. The total quantities of sludge produced in the EU27 are estimated to be around

*Correspondence: nicoleta.suciu@unicatt.it

Department for Sustainable Food Process, Università Cattolica del Sacro Cuore, via Emilia Parmense 84, 29122 Piacenza, Italy
10.13 million tons (dry solids) and expected to increase to 13 million by 2010 [1]. Handling the enormous quantities of sludge entails a significant proportion of the overall operating costs of water-treatment works, and precisely for this reason, appropriate reuse strategies that are sustainable from an environmental and economic point of view are needed.

The main disposal routes of sludge are incineration, sanitary landfill, or use for land-based applications including structural soil improvement, soil buffer, and soil amendment [2]. Application of treated sewage sludge as amendment to land could account for the larger part of the nitrogen and phosphorus requirements for many 
crops. Moreover, the use of sludge on land, principally in agriculture, compared to incineration or sanitary landfill, has lower costs. For this reason in Europe, in particular in the Mediterranean region where high summer temperatures combined with intensive and inappropriate cultivation practices promote a constant decrease in the soil organic matter [3], 40\% of sewage sludge is used as a soil organic amendment due to its high organic matter content [1]. The use of sludge in the agricultural sector varies greatly among Member States. In some EU15 countriesWalloon Region of Belgium, Denmark, France, Ireland, Spain, and the UK-more than half of all sludge production is used in agriculture, but in three of the EU27 Member States, no sludge is used in the agricultural sector (Romania, Brussels Region, and Flemish Region of Belgium), and in six other countries (Finland, Netherland, Romania, Slovakia, Greece, and Slovenia) the amounts are less than $5 \%$ of the total sludge produced [1].

While the use of sewage sludge to bring nutrients and organic matter could be beneficial for the soil, it also represents a risk due to the content of contaminants like heavy metals, organic compounds, and pathogens. Among the organic compounds, the most frequently detected in the municipal sewage sludge include absorbable organic halogens (AOX), linear alkylbenzenesulfonates (LAS), nonylphenols and nonylphenolethoxylates (NP and NPnEOs), di-ethylhexylphthalate (DEHP), polyaromatic hydrocarbons $(\mathrm{PAH})$, polychlorinated biphenyls (PCB), polychlorinated dibenzo-pdioxins and -furans (PCDD/F) as listed in Kapanen et al. [4]. The relative ranges of concentration are $0.09-98 \mathrm{mg} \mathrm{kg}^{-1} \mathrm{dm}$ for LAS, 7.8-13.3 mg kg${ }^{-1} \mathrm{dm}$ for NPs, $0.3-8 \mathrm{mg} \mathrm{kg}^{-1} \mathrm{dm}$ for PAHs, $1.4 \mathrm{mg} \mathrm{kg}^{-1} \mathrm{dm}$ for PCBs, and $>70 \mathrm{mg} \mathrm{kg}^{-1}$ $\mathrm{dm}$ for DEHP [4]. The presence of NP, NPnEOs, and of DEHP is particularly significant due to their wide range of uses. NPnEOs (with $n$ ranging from 1 to 20) are the most extensively used alkylphenol ethoxylates (APnEOs) accounting for $80-85 \%$ of the total use [5]. They are widely employed for industrial, agricultural, and domestic applications as nonionic surfactants. In sewagetreatment plants, NPnEOs undergo a series of rapid transformations, where the polyethoxylate chains break up and generate the short-chain nonylphenols which include nonylphenol (NP), nonylphenolmonoethoxylate (NP1EO), and nonylphenol diethoxylate (NP2EO). Di-ethyl-hexyl phthalate (DEHP) is, among the phthalic acid esters, the most widely studied due to its persistence. Phthalic acid esters are industrial chemicals used as additives in different production process like polyvinylchloride, polyvinylacetate, and cellulosic and polyurethane resins [6]. These compounds have been proven to cause adverse effects, such as reproductive damage, carcinogenicity, and metabolic and obesity diseases [7]. In view of their toxicity and the evidence of pervasive environmental exposure risk, alkylphenol ethoxylates and phthalates/phthalic acid esters have been listed as priority pollutants and restricted due to health concerns [8].

The European Commission is reviewing the Sewage Sludge Directive (86/278/EEC), and in 2000, released a draft-working document on Sludge [9] that sets the frame for monitoring the quality of sewage sludge in Europe. The directive is, at present, completely outdated and sets limit values only for seven heavy metals: cadmium, copper, nickel, lead, zinc, mercury, and chromium in soil and in sludge itself. Any persistent organic pollutants (POPs) are considered. Anyway, the draft document is not legally binding, and only some European Countries (German, Denmark, Sweden, France, and Austria) have set national limits for the organic contaminants in sewage sludge. In 2012, the Joint Research Center [10] published a study aimed at giving technical support for the establishment of an approach to identify and prioritize relevant compounds to be considered in European regulation dealing with Sewage Sludge. Particular emphasis was given to resilience in soil or to the ability to compromise ecosystems adjacent to sludge-receiving soils. The study concluded that repeated occasional surveying of the occurrence of organic pollutants would be useful.

The present paper aims to show the Italian reality, regarding short-chain nonylphenols (NP and NPnEOs with $\mathrm{n}$, indicating the number of ethoxy units, ranging from 1 to 2 ) and phthalates' content in sewage sludge, and to evaluate their potential risk for soil organisms. Furthermore, a comparison with data from other countries is carried out, in order to integrate the Italian reality into a worldwide context. As of date, just very few data have been reported in the literature regarding the presence of short-chain nonylphenols and phthalates' content in sewage sludge. Furthermore, in comparative studies, the Italian reality is never discussed [11, 12].

\section{Methods/experimental \\ Samples and data collection}

The samples (sewage sludge) were collected from 35 wastewater-treatment plants situated in the North of Italy. The samples were stored in a refrigerator at $4{ }^{\circ} \mathrm{C}$ for not more than 7 days and analyzed for the contents of NP, NPnEOs, and DEHP as described in the following Sections. 130 samples were analyzed in the 2-year study, from January 2013 to December 2014.

\section{Solvents and standards}

Solvents used for the extractions of NPs and DEHP from sewage sludge were acetone and hexane, HPLC grade, obtained from Sigma Aldrich and Fluka Co, Steinheim, Germany. Analytical standards for a mixture of NP, 
NPnEOs (4-nonylphenol, 4-nonylphenol-monoethoxylate; 4-nonylphenol diethoxylate), bis(2-ethylhexyl) phthalate (DEHP), and the deuterated internal standards (Anthracene-d10 and Perylene-d12) were purchased from Dr. Ehrenstorfer GmbH, Augsburg, Germany. Calibration curves, prepared by dilution of standard stock solutions with hexane, were obtained at concentrations between $0.005-0.1 \mathrm{mg} \mathrm{L}^{-1}$ and using anthracene $\mathrm{d} 10$ $\left(1.14 \mathrm{mg} \mathrm{L}^{-1}\right)$ and perylene $\mathrm{d} 12\left(1.05 \mathrm{mg} \mathrm{L}^{-1}\right)$ as internal standards. Anhydrous sodium sulfate, (RPE, ISO-for analysis) was obtained from Sigma Aldrich and Fluka Co, Steinheim, Germany.

\section{Sewage sludge extraction}

The samples were prepared by mixing together $20 \mathrm{~g}$ of fresh biological-treated sewage sludge with $20 \mathrm{~g}$ of anhydrous sodium sulfate and then were Soxhlet extracted using $200 \mathrm{~mL}$ of a hexane $(80 \%)$ and acetone $(20 \%)$ mixture for $6 \mathrm{~h}$ [13]. The extract was then concentrated by rotary evaporator, and then under gentle flow of nitrogen, it was dissolved in $1 \mathrm{~mL}$ of hexane containing the internal standards $\left(1 \mathrm{mg} \mathrm{kg}^{-1}\right)$ and analyzed to determine the presence of 4-nonylphenol (NP, $\mathrm{m} / \mathrm{z}$ 107), 4-nonylphenol-mono-ethoxylate; (NP1EO, m/z 179), 4-Nonylphenol diethoxylate (NP2EO, $\mathrm{m} / \mathrm{z} 223$ ), and bis(2-ethylhexyl) phthalate (DEHP, m/z.149).

\section{Gas chromatography-mass spectrometry (GC-MS) determination}

GC-MS analysis was performed using 6890 series gas chromatograph (Agilent Technologies) provided with a mass detector 5973 series MSD (Agilent Technologies) and equipped with a Supelco SLB-5 MS type (5\% polysilarylene-95\% polydimethylsiloxane; $30 \mathrm{~m}$, $0.25 \mathrm{~mm}$ i.d.; $0.25 \mu \mathrm{m}$ film thickness) column. Highgrade helium was used as carrier gas at a constant flow rate of $1.0 \mathrm{~mL} \mathrm{~min}{ }^{-1}$. Injection temperature was $250{ }^{\circ} \mathrm{C}$, injection volume was $1 \mu \mathrm{L}$, injection mode splitless with a purge time of $0.5 \mathrm{~min}$. The $\mathrm{GC}-\mathrm{MS}$ oven temperature was maintained at $140{ }^{\circ} \mathrm{C}$ for $5 \mathrm{~min}$; then increased at a rate of $5{ }^{\circ} \mathrm{C} \mathrm{min}{ }^{-1}$ until $200^{\circ} \mathrm{C}$ and maintained for $5 \mathrm{~min}$; and finally increased at a rate of $10{ }^{\circ} \mathrm{C} \mathrm{min}{ }^{-1}$ until $280{ }^{\circ} \mathrm{C}$ and held there for $15 \mathrm{~min}$. The transfer line temperature was $150{ }^{\circ} \mathrm{C}$ and the MS source was $230{ }^{\circ} \mathrm{C}$. Data were acquired in total ion-monitoring mode (TIM) from $\mathrm{m} / \mathrm{z}$ 50 to 500 , and the compounds were quantified in selected ion-monitoring mode (SIM).

\section{Quality assurance and quality control}

Linearity was tested assessing signal responses of analytes in standard and in matrices over a range of concentrations from 0.005 to $1 \mathrm{mg} \mathrm{kg}-1$. The precision of the method was determined by the repeated intraday analysis on a Certificate Reference Material (CRM) IMEP-21 obtained from the European Commission-JRC-IRMM. Recovery tests were carried out in triplicate at concentrations of 3 and $5 \mathrm{mg} \mathrm{kg}^{-1}$ for DEHP and NPs, respectively. Recovery values for all the NPs compounds ranged from 85 to $125 \%$, with a mean value of $95 \pm 7 \%$. Recovery value for DEHP is $92.145 \pm 9.389$. Limit of quantification (LOQ) of the selected method is $0.003 \mathrm{mg} \mathrm{kg}^{-1}$ for the NPnEOs and DEHP. All results were corrected for the blank values.

\section{Determination of the sewage sludge moisture}

An unextracted portion of sample (20 g) was weighed and transferred to a tarred crucible and dried overnight at $105{ }^{\circ} \mathrm{C}$. The sample was allowed to cool in a dryer before re-weighing. The sewage sludge moisture percentage $(M)$ was calculated as follows:

$$
M=W_{\mathrm{W}}-W_{\mathrm{D}} / W_{\mathrm{W}} * 100,
$$

where $W_{\mathrm{W}}$ is the weight of the wet sample, and WD is the weight of the dry sample.

The dry value concentrations $\left(C_{\mathrm{D}}\right)$ were reported using the percents of solids $\left(P_{\mathrm{S}}\right)$ present in the sample (100-M) as follows:

$$
C_{\mathrm{D}}=C_{\mathrm{W}} / P_{\mathrm{S}} * 100,
$$

where $C_{\mathrm{W}}$ is the wet weight concentration.

Results have been reported on the dry matter basis (dm).

\section{Ecotoxicological risk assessment}

Ecotoxicological risk assessment was evaluated using risk quotients (RQs) for sludge-amended soil. The RQs values represent the ratio between the predicted environmental concentration (PEC) of the selected compounds (NP, NPnEOs, and DEHP) and their predicted no-effect concentration (PNEC). The PECs in soil $\left(\right.$ PEC $\left._{\text {soil }}\right)$ and PNECs in soil $\left(\mathrm{PNEC}_{\mathrm{soil}}\right)$ were calculated as described by Gonzalez et al. [14]. The PECsoil were calculated as per the following the equation:

$$
\mathrm{PEC}_{\text {soil }}=\left(C_{\text {sludge }} * \mathrm{APPL}_{\text {sludge }}\right) /\left(\mathrm{DEHPT} * \mathrm{BD}_{\text {soil }}\right),
$$

where $C_{\text {sludge }}$ is the measured concentration of selected compounds in dry sewage sludge, $\mathrm{APPL}_{\text {sludge }}$ is the drysludge application rate $\left(0.5 \mathrm{~kg} \mathrm{~m}^{-2}\right), \mathrm{DEPTH}_{\text {soil }}$ is the average depth of soil $(0.20 \mathrm{~m})$, and $\mathrm{BD}_{\text {soil }}$ is the bulk density of wet soil $\left(1700 \mathrm{~kg} \mathrm{~m}^{-3}\right)$.

Values for $\mathrm{PNEC}_{\text {soil }}$ were obtained from the $\mathrm{PNEC}_{\text {water }}$ literature data using the equilibrium partitioning approach and the relative soil-water partition coefficient $\left(k_{\mathrm{d}}\right)$ :

$$
\mathrm{PNEC}_{\text {soil }}=\mathrm{PNEC}_{\mathrm{water}} * K_{\mathrm{d}}
$$


$K_{\mathrm{d}}$ is obtained using the following equation:

$$
\mathrm{Kd}=K_{\mathrm{oc}} \times f_{\mathrm{oc}}
$$

where $K_{\mathrm{oc}}$ represents the organic carbon partition coefficient and $f_{\mathrm{oc}}$ the organic carbon fraction in soil. $K_{\mathrm{oc}}$ and $f_{\text {oc }}$ values have been taken from the literature [14].

\section{Results and discussion}

The concentrations of NP, NPnEOs, and DEHP in the sewage sludge, expressed as dry matter $(\mathrm{dm})$, are reported in Figs. 1, 2, and 3, respectively, and in Additional file 1: Table S1. 130 samples from 35 treatment plants in the North of Italy were analyzed during the 2-year study period (2013-2014). The concentrations varied as follows: between $<$ LOD and $0.6583 \mathrm{mg} \mathrm{kg}^{-1}$ $\mathrm{dm}$ for NP, from <LOD to $70.66 \mathrm{mg} \mathrm{kg}^{-1} \mathrm{dm}$ for NP1EO, from 0.4936 to $100.5 \mathrm{mg} \mathrm{kg}^{-1} \mathrm{dm}$ for NP2EO, and from 0.6026 to $148.8 \mathrm{mg} \mathrm{kg}^{-1} \mathrm{dm}$ for DEHP. NPs and DEHP concentrations exceeded the EU/Italian proposed/incharge limit by six and three times, respectively. A high variability in the concentrations of the studied compounds was observed during the sampling period (RSD up 115\%). This fact, as reported by Gonzalez et al. [14], could be due to the high variability of influent wastewater composition over the year and to the wide range of variables that can affect the sludge-treatment process. The studied compounds were detected in $100 \%$ of the analyzed samples, except for the NP that was detected in $23 \%$ of samples. As reported by different authors [15], the concentrations of alkylphenol ethoxylates in fresh water and other environmental compartments could be related to the season and to the temperature, which have an impact on the biological and abiological transformation of NP, NP1EO, and NP2EO. The samples collected during this study were assigned as winter, spring, summer, and autumn samples. The months of January, February, March are considered "winter"; April, May, and June are considered "spring"; July, August, and September are considered "summer"; and October, November, and December are considered "autumn." The highest concentrations of NP, NP1EO, NP2EO, and DEHP were detected during the winter season. These results could demonstrate remarkable seasonal differences in influent concentrations due to differences in the water quantity associated with wash events during the year. A temporal variability of concentrations of DEHP is highlighted in different studies. Some of these studies indicated that concentrations of DEHP change annually as a function of season and runoff, with the highest concentrations of DEHP occurring during the rainy season, the lower concentrations during the dry season, and the lowest concentrations during the transition seasons [16]. Comparing our maximum concentrations with the maximum concentrations from other countries, for example, in sewage sludge from France (Paris), 29 times lower values for NP, ten times higher values for NP1EO, 57 times higher values for NP2EO, and 1.4 times higher values for DEHP were observed as those for Italy [17]. Furthermore, if comparing our maximum concentrations (for Italy) with maximum concentrations in sewage sludge samples from Greece (Athens, Patras), 160 times higher values for NP, three times higher values for the sum of NP1EO and NP2EO, and nine times higher values for DEHP were observed in the Greek sewage sludge samples [18]. A study from Turkey, on sewage sludge samples from Ankara, revealed maximum concentrations for the sum of NP, NP1EO, and NP2EO equal to $20.9 \mathrm{mg} \mathrm{kg}^{-1} \mathrm{dm}$, five times lower than the concentrations for the sum of NP, NP1EO, and NP2EO detected in the current study for Italy [19]. Sewage sludge samples from Hong Kong show maximum organic compounds concentrations equal to $11.7 \mathrm{mg} \mathrm{kg}^{-1} \mathrm{dm}$ for NP, $19.7 \mathrm{mg} \mathrm{kg}^{-1} \mathrm{dm}$ for NP1EO, 5.4 $\mathrm{mg} \mathrm{kg}^{-1} \mathrm{dm}$ for NP2EO, and $37 \mathrm{mg} \mathrm{kg}^{-1} \mathrm{dm}$ for DEHP. Comparing these results with the results obtained in the current study, higher concentration of NP and lower concentrations of NP1EO, NP2EO, and DEHP are observed in sewage sludge samples from Hong Kong [20]. Furthermore, a review study of the Joint Research Center of the European Commission [10] show that sewage sludge concentrations of NP and the respective ethoxylates in the European Union countries vary over a wide range, and a remarkable decline in NP contamination range is noticeable comparing the latest available data with results from earlier investigations. The same study shows concentrations of $\mathrm{Np}$ and $\mathrm{NPnEO}$ ( $n$ from 1 to 2 ) varying from 0.04 to $650 \mathrm{mg} \mathrm{kg}^{-1}$ $\mathrm{dm}$ (median $5.1 \mathrm{mg} \mathrm{kg}^{-1} \mathrm{dm}$ ) and of DEHP varying from 1.5 to $3513.8 \mathrm{mg} \mathrm{kg}^{-1} \mathrm{dm}$, while in the present study the NP, NPnEO, and DEHP concentrations vary from 1.32 to $103 \mathrm{mg} \mathrm{kg}^{-1} \mathrm{dm}$ (median $6.24 \mathrm{mg} \mathrm{kg}^{-1} \mathrm{dm}$ ) and from 0.602 to $148 \mathrm{mg} \mathrm{kg}^{-1} \mathrm{dm}$ (median $11.1 \mathrm{mg} \mathrm{kg}^{-1} \mathrm{dm}$ ), respectively. In conclusion, there are huge variations of

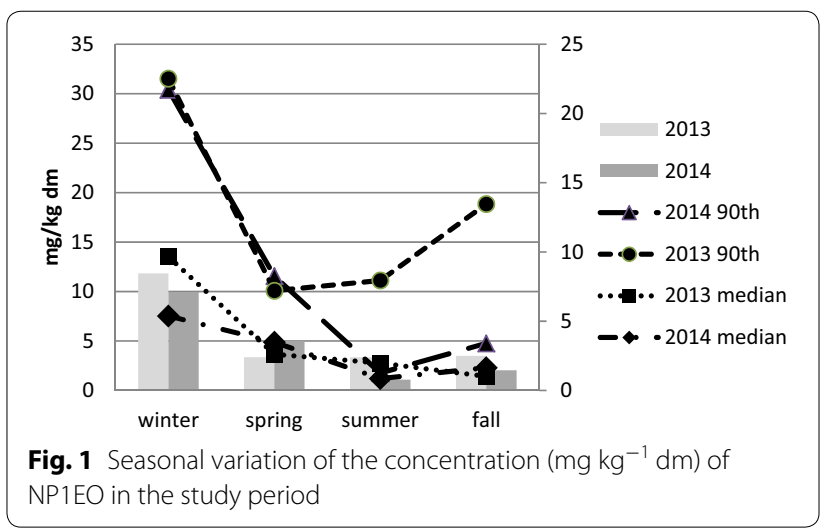




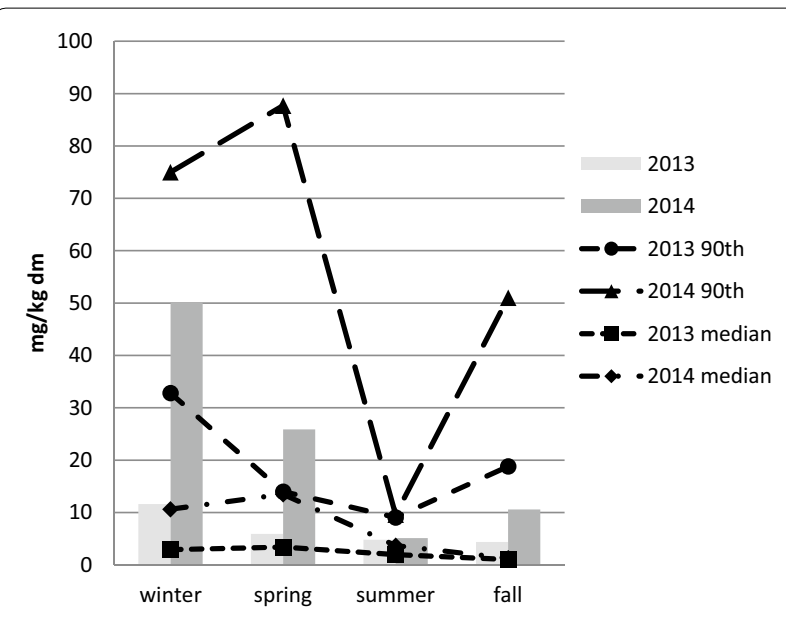

Fig. 2 Seasonal variation of the concentration $\left(\mathrm{mg} \mathrm{kg}^{-1} \mathrm{dm}\right)$ of NP2EO in the study period

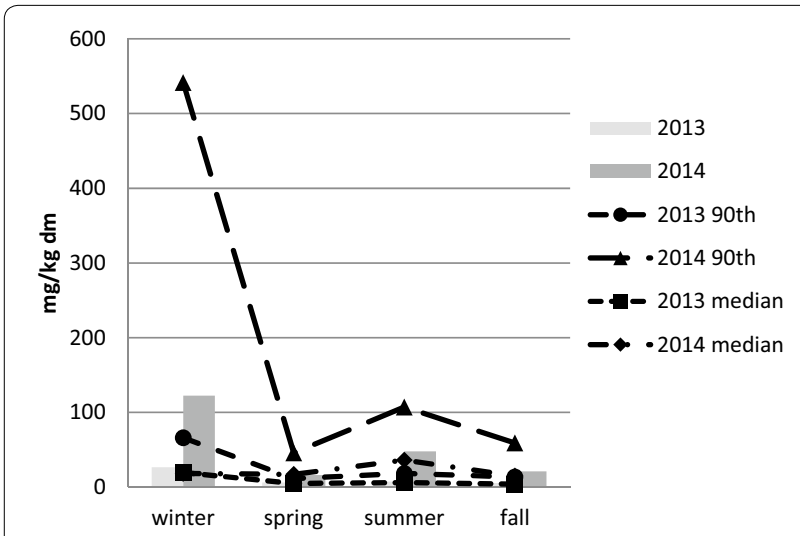

Fig. 3 Seasonal variation of the concentration $\left(\mathrm{mg} \mathrm{kg}^{-1} \mathrm{dm}\right)$ of DEHP in the study period

NP, NPnEO, and DEHP concentrations on sewage sludge from different European and Asiatic countries, including Italy. However, the sewage sludge in Italy shows a lower concentration of NP than the sewage sludge samples from other countries, except Turkey, whereas the concentrations of NPnEOs and DEHP were in almost all the cases higher than in the countries considered for the comparison.

Calculated risk quotients in sludge-amended soil were, for the NPnEOs, lower than 1. PNEC $_{\text {soil }}$ values for NP, NPnEOS, and for DEHP were obtained from $\mathrm{PNEC}_{\text {water }}$. Also if there is not a general agreement

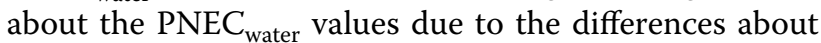
the results of toxicities studies [21], the lowest value among the available values from literature was used to obtain a conservative value. In this study, a $\mathrm{PNEC}_{\text {water }}$ value of $0.28 \mu \mathrm{g} \mathrm{kg}^{-1}$ [22] was used for NP, while a value of $0.11 \mu \mathrm{g} \mathrm{kg}-1$ was used for both NP1EO and NP2EO [10]. For DEHP, the $\mathrm{PNEC}_{\text {water }}$ value of $0.04 \mu \mathrm{g} \mathrm{kg}^{-1}$, as obtained from Liu et al. [23], was used.

\section{Conclusion}

- The occurrence of NP, NP1EO, NP2EO, and DEHP in 130 samples of sewage sludge from 35 wastewatertreatment plants in the North of Italy has been studied for 2 years.

- Less than $5 \%$ of sludge samples analyzed contained NPnEOs (sum of NP, NP1EO, and NP2EO) concentrations higher than the limit of $50 \mathrm{mg} \mathrm{kg}^{-1} \mathrm{dm}$ fixed by the EU Directive Draft. Less than $2.5 \%$ of sludge samples analyzed contained DEHP concentrations higher than the limit of $100 \mathrm{mg} \mathrm{kg}^{-1} \mathrm{dm}$. Comparing the obtained data with data from other European and Asiatic countries, huge variations of the NP, NPnEOs, and DEHP concentrations in sewage sludge samples were observed. However, the sewage sludge in Italy show a lower concentration of NP than the sewage sludge samples from other countries, except Turkey, whereas the concentrations of NPnEOs and DEHP in Italy were in almost all the cases higher than those in the countries used for the comparison. Concerning the toxicological assessment, RQs reveal also that if NP (RQ 0-0.019) has the lowest PNEC (due to the lowest $\mathrm{K}_{\mathrm{oc}}$ value), it presents lower risk for soil organisms than NP1EO (range 0-0.54) and NP2EO (0.003-0.58). However, the RQs calculated for the DEHP range from $7 \times 10^{-3}$ to 1.7 , exceeding the value of 1 three times.

- According to the results for Italy, the use of sewage sludge with agricultural purposes would be restricted and regulated but not prevented. In general, based on the results of the RQs calculation, the proposed EU limits, for the sum of NPnEOs ( $n$ ranging from 0 to 1 ) and DEHP on sewage sludge intended to be used as soil fertilizer in agriculture, as 50 and $100 \mathrm{mg} \mathrm{kg}^{-1} \mathrm{dm}$, respectively, are sufficiently conservative to avoid negative effects on soil fauna.

- As the results show (Figs. 1, 2, and 3 and Additional file 1: Table S1), regarding the years 2013-2014, it could be stated that concentrations of the investigated compounds in sewage sludge of municipal WWTPs in Italy have predominantly increased. However, the increasing trends for the analytes in the sewage sludge have to be investigated deeply with detailed and additional measurements. An analysis of the sewage sludge related to each wastewater-treatment plant could be useful to analyze the trend and to exclude that some single WWTP that could represent a hot-spot due to the wastewater input or due to the treatment pattern that could be outdated. 
- The continuous research of technologies useful in sludge management to decrease the concentration of the organic pollutants together with continuous sludge analysis must be considered strategic for the sustainable reuse of sludge.

\section{Additional file}

Additional file 1. NP, NP1EO, NP2EO, DEHP range (min, max values) and median concentration in sewage sludge during the present study (2013-2014).

\section{Authors' contributions}

All the authors wrote the original draft of the manuscript. All the authors read and approved the final manuscript.

\section{Acknowledgements}

The authors would like to thank Prof. Raffaella Boccelli and Pierluisa Fantini for their support for sewage sludge sample supply and preparation.

\section{Competing interests}

The authors declare that they have no competing interests.

\section{Availability of data and materials}

Other data and materials could be made available upon request to the corresponding author.

\section{Ethics approval and consent to participate}

Not applicable.

\section{Funding}

Not applicable.

\section{Publisher's Note}

Springer Nature remains neutral with regard to jurisdictional claims in published maps and institutional affiliations.

Received: 22 December 2017 Accepted: 24 April 2018

Published online: 04 May 2018

\section{References}

1. Milieu Ltd, WRc, Risk and Policy Analysts Ltd (RPA). Environmental, economic and social impacts of the use of sewage sludge on land. Final Report, Part III: Project Interim Reports; 2010. DG ENV.G.4./ ETU/2008/0076r. http://ec.europa.eu/environment/archives/waste/ sludge/pdf/part_iii_report.pdf. Accessed 2 May 2018.

2. Babatunde $\mathrm{AO}, \mathrm{ZhaO} \mathrm{YQ}$. Constructive approaches toward water treatment works sludge management: an international review of beneficial Reuses. Crit Rev Environ Sci Technol. 2007;37:129-64.

3. González-Ubierna S, Jorge-Mardomingo I, Carrero-González B, de la Cruz MT, Casermeiro MÁ. Soil organic matter evolution after the application of high doses of organic amendments in a Mediterranean calcareous soil. J Soils Sediments. 2012;12:1257-68.

4. Kapanen A, Vikman M, Rajasärkkä J, Virta M, Itävaara M. Biotests for environmental quality assessment of composted sewage sludge. Waste Manag. 2013:33:1451-60.

5. Loyo-Rosales JE, Rice CP, Torrents A. Fate and distribution of the octyland nonylphenol ethoxylates and some carboxylated transformation products in the Back River, Maryland. J Environ Monit. 2010;12:614-21.

6. Stasinakis AS, Gatidou G, Mamais D, Thomaidis NS, Lekkas TD. Occurrence and fate of endocrine disrupters in Greek sewage treatment plants. Water Res. 2008;42:1796-804.

7. Pak VM, McCauley LA, Pinto-Martin J. Phthalate exposures and human health concerns: a review and implications for practice. AAOHN J. 2011;59:228-33.
8. European Commission. 2012. http://ec.europa.eu/environment/water/ waterframework/priority_substances.htm. Accessed 04 Apr 2018.

9. European Comission. European Commission Working Document on Sludge. Third Draft, Brussels 27 April 2000, DG Environment; 2000. http:// ec.europa.eu/environment/waste/sludge/pdf/sludge.en.pdf. Accessed 2 May 2018.

10. JRC. Occurrence and levels of selected compounds in European Sewage Sludge Samples, EUR 25598 EN; 2012.

11. Fijalkowski K, Rorat A, Grobelak A, Kacprzak MJ. The presence of contaminations in sewage sludge-the current situation. J Environ Manage. 2017:203:1126-36.

12. Kacprzak M, Neczaj E, Fijalkowski K, Grobelak A, Grosser A, Worwag M, Rorat A, Brattebo H, Almas A, Singh BR. Sewage sludge disposal strategies for sustainable development. Environ Res. 2017;156:39-46.

13. Suciu NA, Lamastra L, Trevisan M. PAHs content of sewage sludge in Europe and its use as soil fertilizer. Waste Manag. 2015;41:119-27.

14. Gonzalez MM, Martin J, Santos JL, Aparicio I, Alonso E. Occurrence and risk assessment of nonylphenol and nonylphenol ethoxylates in sewage sludge from different conventional treatment processes. Sci Total Environ. 2010;408:563-70.

15. Gao D, Li Z, Guan J, Liang H. Seasonal variations in the concentration and removal of nonylphenol ethoxylates from the wastewater of a sewage treatment plant. J Environ Sci. 2016. https://doi.org/10.1016/j. jes.2016.02.005

16. Lu P. Investigation of pollution and health risk assessment of plasticizers in source and drinking water of Hefei. Hefei: Anhui Medical University; 2013. p. 59-63.

17. Mailler R, Gasperi J, Patureau D, Vulliet E, Delgenes N, Danel A, Deshayes S, Eudes V, Guerin S, Moilleron R, Chebbo G, Rocher V. Fate of emerging and priority micropollutants during the sewage sludge treatment: case study of Paris conurbation. Part 1: contamination of the different types of sewage sludge. Waste Manag. 2017;59:379-93.

18. Pakou C, Kornaros M, Stamatelatou K, Lyberatos G. On the fate of LAS, NPEOs and DEHP in municipal sewage sludge during composting. Biores Tech. 2009;100:1634-42.

19. Omeroglu S, Murdoch FK, Sanin DF. Investigation of nonylphenol and nonylphenol ethoxylates in sewage sludge samples from a metropolitan wastewater treatment plant in Turkey. Talanta. 2015;131:650-5.

20. Wu Q, Lam JCW, Kwok KY, Tsui MMP, Lam PKS. Occurrence and fate of endogenous steroid hormones, alkylphenol ethoxylates, bisphenol $A$ and phthalates in municipal sewage treatment systems. J Env Sci. 2017:61:49-58

21. Soares A, Guieysse B, Jefferson B, Cartmell E, Lester JN. Nonylphenol in the environment: a critical review on occurrence, fate, toxicity and treatment in wastewaters. Environ Int. 2008;34:1033-49.

22. Gao P, Li Z, Gibson M, Gao H. Ecological risk assessment of nonylphenol in coastal waters of China based on species sensitivity distribution model. Chemosphere. 2014;104:113-9.

23. Liu N, Wang Y, Yang Q, LV Y, Jin X, Giesy JP, Johnson AC. Probabilistic assessment of risks of diethylhexyl phthalate (DEHP) in surface waters of China on reproduction of fish. Environ Pollut. 2016:213:482-8.

\section{Submit your manuscript to a SpringerOpen ${ }^{\circ}$ journal and benefit from:}

- Convenient online submission

Rigorous peer review

- Open access: articles freely available online

- High visibility within the field

- Retaining the copyright to your article

Submit your next manuscript at springeropen.com 